J Pediatr Health Care. 2011 ; 25(4): 208-215. doi:10.1016/j.pedhc.2009.12.006.

\title{
Health-Related Quality of Life in Children and Adolescents with Sickle Cell Disease
}

\author{
Juanita Conkin Dale, Ph.D., RN, CPNP-PC, Cindy J. Cochran, MSN, RN, CPNP-PC, Lonnie \\ Roy, Ph.D., and Ethel Jernigan, LMSW-AP \\ Children's Medical Center Dallas, TX
}

George R. Buchanan, MD

Southwestern Comprehensive Sickle Cell Center Department of Pediatrics, University of Texas Southwestern Medical Center at Dallas

\begin{abstract}
Objective-To assess health-related quality of life (HRQOL) in children and adolescents with sickle cell disease (SCD).

Design, Setting, and Participants-The PedsQL TM 4.0 Generic Scales, a multidimensional self-report instrument that has been shown to be valid and reliable for use in children and adolescents with chronic illness, consists of 23 items that assess physical, emotional, social, and school functioning. Questionnaires were administered to 124 children and adolescents (aged 8-18 years, child self-report) with SCD (100 sickle cell anemia [SS], 24 sickle beta zero thalassemia $\left[\mathrm{S} \beta^{0}\right.$ thal]) and their parents (parent-proxy report). Summary scores for children's and parents' ratings of overall HRQOL and psychosocial health and subscale scores for physical, emotional, social, and school functioning were compared to published data for healthy children. Both summary and subscale scores for children with SCD were also compared to those of their parents.
\end{abstract}

Results-Children with SCD and their parents rated overall HRQOL and all sub-domains of HRQOL lower than ratings of healthy children and their parents $(p<.001)$. Children with SCD rated their own HRQOL significantly better than their parents for overall HRQOL and all subdomains ( $p<.001)$ except emotional functioning $(p=.06)$.

Conclusions-Children with SCD and their parents perceived overall HRQOL and all HRQOL sub-domains to be lower than scores reported in healthy children. Therefore, successful therapeutic efforts to improve HRQOL could represent important advances in the health of children with SCD.

\section{Keywords}

Quality of Life; Health Related Quality of Life; Sickle Cell Disease; Chronic Illness; Children and Adolescents

(C) 2010 National Association of Pediatric Nurse Associates and Practitioners. Published by Mosby, Inc. All rights reserved. Corresponding Author: Juanita Conkin Dale, Ph.D., RN, CPNP-PC Children's Medical Center Pediatric Neurology 1935 Medical District Drive Dallas, TX 75235 Fax: 214-456-6898 Telephone: 214-456-2768 juanita.dale @ childrens.com.

This work was presented in part at the $28^{\text {th }}$ Annual Meeting of the National Sickle Cell Disease Program, Cincinnati, OH, April 11, 2005.

None of the authors report any financial interest or potential conflicts of interest.

Publisher's Disclaimer: This is a PDF file of an unedited manuscript that has been accepted for publication. As a service to our customers we are providing this early version of the manuscript. The manuscript will undergo copyediting, typesetting, and review of the resulting proof before it is published in its final citable form. Please note that during the production process errors may be discovered which could affect the content, and all legal disclaimers that apply to the journal pertain. 
Sickle cell disease (SCD) is one of the most common genetic disorders affecting 1 in every 500 African-American births and 1 in 1000 to 1400 Hispanic-American births in the United States (Human Genome Project, 2005). Children and adolescents with SCD may require hospitalization for acute complications such as painful episodes, acute chest syndrome, splenic sequestration, infection, stroke, aplastic crisis, and priapism. Common chronic complications of SCD include also pigment gallstones, delayed growth and development, avascular necrosis, pulmonary hypertension, and renal disease. Management of these complications may require hospitalization or treatment at home, in an ambulatory setting, or in the emergency department (ED), thus affecting attendance at school and normal play activities. These hospitalizations and school absences could be expected to have a negative impact on the health-related quality of life (HRQOL) for children and adolescents with SCD (Okpala et al., 2002; Ramsey et al., 2001; Serjeant, 1993; Strickland, Jackson, Gilead, McGuire, \& Quarles, 2001; Thomas \& Taylor, 2002; Wethers, 2000). Limited data suggest that certain aspects of SCD, such as pain, negatively affects the patient and that specific treatments, such as hydroxyurea (HU), stem cell transplantation (SCT), or physical therapy, may improve HRQOL (Fuggle, Shand, Gill, \& Davies, 1996; Ramsey, et al, 2001; Wethers, 2000). Ballas and colleagues (2008) reported, based on the results from that Multicenter Study of Hydroxyurea in Sickle Cell Anemia (MSH), that hydroxyurea improves some aspects of quality of life in adults patients who have moderate to severe sickle cell anemia.

The World Health Organization (1946) defines health as being not only the absence of disease and infirmity, but also the presence of physical, mental and social well being. Health-related QOL refers to the physical, psychological and social domains of health seen in areas influenced by a person's experiences, beliefs, expectations, and perceptions (Testa \& Simonson, 1996). The closer a person's life is to the standard of normalcy, the better the HRQOL (Ferrans, 1995). Several HRQOL studies have examined children and adolescents with various health conditions such as chronic pain, obesity, cancer, recurrent otitis media, and HIV infection (Brouwer et al., 2005; Lee, Gortmaker, McIntosh, Hughes, \& Oleske, 2006; Shankar et al., 2005; Speechley, Barrera, Shaw, Morrison, \& Maunsel, 2006; Swallen, Reither, Haas, \& Meier, 2005; Williams, Wake, Hesketh, Maher, \& Waters, 2005).

Palermo and colleagues (2002) used the Child Health Questionnaire (CHQ) - Parent Report to compare HRQOL of 58 children with SCD to a demographically similar group of 120 healthy children and found that SCD negatively affected HRQOL. Caregivers reported more limited physical, psychological, and social well-being compared to healthy children. Factors that were predictive of limitations in physical functioning included age, female gender, and more disease-related complications. Stegenga and colleagues (2004) used semi-structured interviews of 10 children with sickle cell disease to explore, from the child's perspective, how their quality of life is affected by chronic transfusion therapy. Five themes emerged from the data: pain, school issues, disease knowledge, transfusion therapy, and having had a stroke as factors that might impact the HRQOL of children with SCD. Panepinto and colleagues (2004) administered the CHQ to 95 children with SCD ages 5 to 18 years and found the instrument valid. Compared to children, parents reported worse HRQOL in overall perception of health, physical functioning, behavior, and self esteem domains. Parent and child reports correlated strongly for impact of bodily pain, and moderately for physical functioning, behavior, general health, self esteem, and changes in health domains. In a subsequent study, Panepinto and co-workers (2005) administered the CHQ-Child Form to 53 children with SCD and the CHQ-Parent Form to 95 parents/caretakers. They confirmed that children with SCD had significantly impaired HRQOL when compared to non-white healthy children. Panepinto and colleagues (2009) subsequently used the PedsQL ${ }^{\text {TM }} 4.0$ to determine the impact of family income and SCD on the HRQOL of children. They administered the PedsQL ${ }^{\text {TM }} 4.0$ parent-proxy or child self-report questionnaire to 104 
children with SCD and 72 children without disease. They concluded that children with SCD have significantly impaired HRQOL even after considering the potential detrimental effect of family income on HRQOL. Hankins et al. (2007) investigated the decision-making process among patients with SCD (7 patients) and their families (21 parents) to better understand why they selected a specific treatment (CT, HU, SCT) or declined therapy. They used the PedsQL ${ }^{\text {TM }} 4.0$ to determine the relationship between treatment preferences with HRQOL and the severity of recent vaso-occlusive events (VOE). They concluded that the HRQOL scores for the three groups studied did not differ significantly except for the scores of the parents preferring HU being significantly lower than their children's self-reported scores.

In the past decade, more studies have been published describing overall HRQOL in children and adolescents with sickle cell disease (Hankins et al., 2007; Palermo, Schwartz, Drotar, \& McGowan, 2002; Panepinto, O'Maher, DeBaun, Loberiza, \& Scott, 2005; Panepinto, O'Maher, DeBaun, Rennie, \& Scott, 2004; Panepinto, Pajewski, Foerster, Sabnis, \& Hoffman, 2009; Stengenga, Ward-Smith, Hinds, Routhieaux, \& Woods, 2004). We conducted a study to further assess HRQOL in these patients, with the primary hypothesis that HRQOL of children and adolescents with SCD was less than that of healthy children and adolescents.

\section{Methods \\ Participants}

A convenience sampling technique was used to select patients followed in a Pediatric Sickle Cell Disease Program at a children's medical center in a Southwestern metropolitan area between March 2003 and October 2004. Approximately 600 active patients are followed in the program. For the purpose of this research, only children and adolescents between the ages of 8 and 18 years with sickle cell anemia (SS) or sickle beta zero thalassemia ( $\mathrm{S} \beta^{0}$ thal), the most severe disease forms, were included. Institutional Review Board approval was obtained.

The families were approached during a regularly scheduled clinic visit to determine their interest in participating in the study. Study eligibility included the ability to read, write, or verbalize an understanding of written concepts as read to them and to speak either English or Spanish. The staff of the hospital's Translation Services Department was utilized to obtain consent and assist the one Spanish speaking teenager and her parent in completing the questionnaire. Patients were excluded from this study if they had previously experienced a stroke, were on a chronic transfusion (CT) program, or were experiencing an acute complication of their disease at the time of their clinic visit. The research staff explained the study, obtained written consent/assent, and assisted the child and/or parent with completing the demographic and PedsQL ${ }^{\mathrm{TM}} 4.0$ questionnaires if necessary. As an incentive to participate, a token reward of a restaurant gift certificate was given to the family.

\section{Comparison group}

Data published by Varni and his colleagues (2003) were used as the comparison group. The 10,241 participants in their study included families with children 2 to 16 years of age, who were newly enrolled in the State's Children's Health Insurance Program (SCHIP) throughout the State of California during February and March 2001. The parent and/or child was English, Spanish, Vietnamese, Korean, or Cantonese speaking. 


\section{PedsQLTM 4.0}

The PedsQL ${ }^{\text {TM }} 4.0$ was chosen for this study because it is valid and reliable for use with healthy and chronically ill children between the ages of 2 and 18 years, brief ( 23 items), practical (taking less than ten minutes to complete), flexible, developmentally appropriate, multi-dimensional and responsive to clinical change (Varni, Burwinkle, Seid, Uzark, \& Szer, 2002). The PedsQL ${ }^{\text {TM }} 4.0$ uses a Likert scale to measure opinions or attitudes about problems related to physical, emotional, social and school functioning. The parent/proxy survey asks the same questions as the child and adolescent questionnaire and documents the parent's perception of their child's function in each of the above domains. A Spanish version of the PedsQL ${ }^{\text {TM }} 4.0$ Generic Model is also available. The companion PedsQL ${ }^{\text {TM }}$ Family Information Form was used to obtain demographic and other information pertaining to the impact that the child's illness may have on the family such as school days missed by the child or work days missed by the parent, number of days in the hospital, and ED visits. Data were also collected to identify the child's SCD genotype, grade in school, any siblings with $\mathrm{SCD}$, and other chronic diseases.

\section{Statistical Analysis}

Data were analyzed using SPSS version 13.0 for Windows and Microsoft Excel software packages for data management and analysis. Demographic data were analyzed as means, standard deviations and frequency distributions. One sample $t$-tests were used to test for significant differences between the healthy child data and the children with SCD. Parent and child differences in perceptions of HRQOL were tested with a 1 factor within (parent-child response) GLM ANOVA model. Associations between HRQOL and hospitalizations and emergency visits were tested with Pearson's correlation analyses.

The power of this study to detect a significant difference was based on hypothesized effect sizes for the primary outcome variable (children's overall HRQOL score) as well as one of the sub-scales of special concern for children with SCD, school functioning. The criterion for significance (alpha) was set at .05, with 2-tailed test, and 95\% confidence intervals. The validation study results (means and standard deviations) from the developers of the PedsQL ${ }^{\text {TM }} 4.0$ instrument were used for HRQOL estimates for healthy children and for those with chronic diseases in the power analyses (Varni, Burwinkle, Seid, \& Skarr, 2002). Because parameter estimates were available from the developers of the questionnaire for both child and parent responses, power was determined for the overall HRQOL score and each of the sub-scales for child and parent respondents separately. A sample size of 120 children (and one parent/proxy of each child) was chosen to maximize the probability of achieving a significant result for the primary outcome variable (>90\% power) and to provide adequate power for the school functioning sub-scale (80\%). For the sample of 120 parents, power exceeded $90 \%$ for all scales.

\section{Results}

\section{Description of Participant Population}

During the enrollment period, 234 patients were seen in the Sickle Cell Clinic who met criteria for enrollment in the study. Among those patients, 124 participated in the study and 6 declined participation. For a variety of reasons, the other 104 potential study participants who were eligible were not approached about being enrolled in the study.

As seen in Table I, this study's participants averaged 13 years of age and grade seven at school. All but one was African American and approximately 52\% were male. About half of the mothers and nearly $66 \%$ of the fathers had a high school education or less. Regarding health and daily functioning, during the previous month these children averaged about 3 
days of reduced activity levels (school or play) and needed care because of their illness. Fifty percent of the children were hospitalized and 74\% visited an ED during the past year. Moreover, the caregivers said that within the prior 30 days, their child's health problems interfered with their own daily work routine $(20 \%)$ or with their ability to concentrate $(27 \%)$.

\section{Healthy Child Population Comparisons}

Significant differences in HRQOL were found between published healthy child scores (Varni et al. 2003) and those of children with SCD and as determined by both the children themselves and their parent proxies. Specifically, children with SCD had significantly lower overall HRQOL than that reported for healthy children and lower scores in every subdomain as well (see Table II). Because patients with SCD are predominately AfricanAmerican, a secondary analysis was undertaken with healthy African-American children as the comparison group. Significant differences again were found in the children with SCD and their parents compared to published normative mean overall HRQOL scores (Varni et al. 2003) for African-American children $(n=143$, mean $=81.8, S D=13.1, p<.001)$ and their parents $(n=239$, mean $=82.9, S D=13.6, p<.001)$.

\section{Healthcare Utilization}

The association between HRQOL and number of hospitalizations and ED visits was explored with correlational analyses. Among the child responses, only one correlation achieved statistical significance $(p=.018)$. A weak, inverse correlation $(-.212)$ was observed for the school dimension with number of hospitalizations, although not found for number of ED visits. This indicates that increased hospitalizations were correlated with lower HRQOL school functioning scores. Among parent reports, four significant correlations were observed for hospitalizations: overall HRQOL $(-.206 ; p=022)$, and emotional $(-.198 ; p=.029)$, school $(-.184 ; p=.042)$, and the psychosocial health dimension $(-.217 ; p=.016)$. All were weak to moderate inverse correlations. One significant correlation was observed for ED visits and the emotional dimension $(-.201 ; p=$. 026). Increased hospitalizations, and in the one case ED visits, were correlated with lower scores for each of these dimensions.

\section{Child/Parent Comparisons}

Children with SCD described their own HRQOL as significantly better than their parents perceived it to be. Significant differences between parent and child ratings in our study were observed for overall HRQOL and all sub-domains except the emotional functioning subdomain where it approached statistical significance ( $p=.06$, see Table II).

\section{Discussion}

Our findings in children with SCD were similar to those found in children with other chronic conditions (Gold et al., 2009; Shankar et al, 2005; Speechley et al., 2006; Varni, Burwinkle, Seid, 2006) in that the HRQOL was reported as decreased when compared to healthy children. Specifically, the mean score (68.6) among our patients with SCD for overall HRQOL was consistent with that found for children with other severe chronic health conditions such as newly diagnosed cancer receiving treatment (68.9) and rheumatoid arthritis (72.1) (Varni et al., 2006). This earlier study, like ours, indicates a discrepancy in HRQOL assessment between the parents and children themselves, with the children consistently reporting their HRQOL to be better than that described by their parents.

Our primary hypothesis of overall HRQOL of children and adolescents with SCD being lower than that of healthy children and adolescents, including African-Americans, was 
supported by our findings. The PedsQL ${ }^{\text {TM }} 4.0$ has been found to be valid and reliable in the age groups examined in this study, and its ease of completion (usually about 10 minutes) and its 23 short questions proved highly efficient for use in a busy outpatient clinical setting. Further, unlike the other HRQOL instruments, the questions in the child and adolescent selfreport and the parent proxy-report were identical, thus facilitating comparisons between the two groups.

A difference in overall perception of HRQOL and in the various sub-domains of children with SCD compared to their healthy counterparts was apparent. However, a significant effect between the age groups was not apparent by the child and adolescent self-reports. Our results further demonstrated that parents of children and adolescents with SCD perceive their child's HRQOL differently than the parents of healthy children and adolescents. This was similarly noted by Palermo et al (2002) and Panepinto et al (2004, 2005). Parents of children and adolescents with SCD rated the overall HRQOL, as well as all of the subdomains, lower than their healthy counterparts. The results of this and other studies in children mirror published data in adults with SCD, which show diminished HRQOL across most domains (McClish, Penberthy, Bovbjerg, Roberts, Aisiku, Levenson et al., 2005; Thomas \& Taylor, 2002).

While not a primary study question, we found that there was a weak inverse relationship between the number of hospitalizations and ED visits and overall HRQOL and most of the sub-domains. This finding supports what others (Okpala et al., 2002; Ramsey et al., 2001; Serjeant, 1993; Strickland, Jackson, Gilead, McGuire, \& Quarles, 2001; Thomas \& Taylor, 2002; Wethers, 2000) have written and is not surprising considering the fact that many complications of SCD require treatment either in the ED or hospital. Further inquiry into this will require prospective hypothesis driven studies.

The mean overall HRQOL and physical health QOL scores for both the child self-report and parent report in the current study were slightly more than one standard deviation (1SD) below the normative child population scores published by Varni and coworkers (2003). These investigators compared the mean scores of healthy children to those of children chronic health conditions such as cancer and rheumatic disease (Varni et al, 2006) and found that such children had scores at least $1 S D$ below the mean score of the healthy population (Varni et al, 2003). They proposed that if children with a chronic condition have scores that are $1 S D$ or more below the child population mean, it places them "at risk" for impaired HRQOL. Using these criteria, 53\% and $63 \%$ of the children with SCD would be "at risk" for impaired overall HRQOL and physical health QOL respectively. Further, although the psychosocial, emotional, social, and school functioning sub-domains mean scores were not 1 $S D$ or more below the healthy population means, substantial proportions ( $28 \%$ to $55 \%$ for child self-reports) of the SCD patients are still be "at risk" for these dimensions using this definition (see Table III).

Our study found that a large proportion of children with SCD would be "at risk" for impaired overall HRQOL, as well as the sub-domains of physical health and school functioning. These findings could have substantial clinical implications. First, as other studies also found, children with SCD express lower mean HRQOL levels than healthy children, similar to children with other chronic diseases (Palmero, et al, 2002; Panepinto et al, 2004; Panepinto et al, 2005). Second, a large proportion of children with SCD could be classified as "at risk," not just expressing lower mean scores than healthy children. This suggests that screening children with SCD for HRQOL is warranted. Moreover, given the large proportion of children with SCD in this study that could be identified as "at risk" for impaired quality of life, and the now well recognized need to maintain psychosocial well being among children and adults alike, we believe there is a real need in clinical practice to 
offer treatments such as $\mathrm{CT}, \mathrm{HU}$, or $\mathrm{SCT}$ and even more importantly to provide psychosocial interventions such as assistance with school work, counseling, or play therapy. With knowledge of the specific sub-domains for which a child may be more or less "at risk," interventions can be developed and tailored to address the specific quality of life need or needs of each child with SCD. By intervening in childhood, the HRQOL of children may improve and thus improve the HRQOL of these individuals when they reach adulthood.

The American Academy of Pediatrics (AAP) published recommendations for Health Supervision for Children with Sickle Cell Disease in 2002 and reaffirmed those recommendations in 2006. In addition to recommendations regarding evaluation and treatment of acute illnesses in children with sickle cell disease, they proposed that comprehensive care should include periodic psychosocial assessments. They further proposed that access to services is needed to optimize the patient's and family's adaptation to chronic illness because personal and cultural beliefs about illness and existing stresses and support systems may impact their ability to cope with SCD.

The strengths of our study include a larger number of participants than other studies evaluating HRQOL in children and adolescents with SCD. The data reported in Table I compares our participants to the larger number of healthy children (Varni et al., 2003); however, as previously stated, we also compared our participants' scores to those of the 143 African-American children in their study. Moreover, our study population was relatively homogenous in that it included only children and adolescents with SS or $\mathrm{S}^{0}$ thal, the most severe forms of SCD. Patients with clinically less severe genotypes were not enrolled. In designing the study, we believed that limiting the study participants to the more severe forms of the disease ( $\mathrm{SS}$ or $\mathrm{S}^{0}$ thal) and excluding those on chronic transfusion, history of stroke or currently experiencing an acute complication would provide a more homogenous sample. A chronic transfusion program alters the clinical course, rendering the child with SCD less likely to experience complications such as painful episodes, acute chest syndrome, or stroke. Although there are PedsQL TM 4.0 Generic Models for use with younger children, we chose to limit our study to children 8 to 18 years of age because we believed that age group would better be able to complete the questionnaire independently. Further, enrollment occurred in the outpatient setting when the participants were in steady state and not having pain.

Our study has limitations. First, we did not explore the effect of disease severity on HRQOL due to the lack of an acceptable definition for milder versus more severe disease. Children with SCD whose disease course is more severe would be expected to have lower HRQOL than patients without multiple hospitalizations, unscheduled outpatient visits, and school absences. In this study, we did not collect these event data. Defining "severe" (in contrast to "typical" or "mild") SCD has been problematic. It is customary to designate patients as being severely affected based on their having had a devastating complication, e.g., septicemia or stroke, or their having numerous vasoocclusive events annually that require medical attention. Yet, criteria assessing disease severity vary with age, and no global severity instruments have been validated.

Another limitation to this study is our failure to determine whether specific therapeutic interventions improved HRQOL. Patients receiving chronic transfusions were excluded. Only 12 of the study patients were receiving hydroxyurea at the time that they participated in the study and 22 others had been previously treated with hydroxyurea, but were no longer receiving it. Future prospective studies of these and other interventions should include assessment of HRQOL outcomes. 
Finally, a substantial limitation of all HRQOL studies involving SCD, including this one, is that generic rather than disease-specific instruments have been employed. Badly needed is the design, testing, and validation of tools that capture the nuances of SCD as a chronic illness with unique physical and psychosocial problems that differ appreciably from cancer, HIV infection, and other chronic childhood disorders. A disease-specific instrument would likely be much more sensitive than a generic one to detect changes as a result of therapeutic interventions.

Ratings by parents were significantly lower than those of their children for all sub-domains except emotional functioning. Because children with SCD and some other chronic conditions report their HRQOL as higher than their parents' perception(es), it is imperative that both the child and parent be allowed to provide their perception regarding the child's HRQOL.

\section{Conclusions}

Children with SCD and their parents perceived overall HRQOL and all HRQOL subdomains to be lower than scores reported in healthy children. Therefore, successful therapeutic efforts to improve HRQOL could represent important advances in the health of children with SCD. Furthermore, as stated by Panepinto (2008), through measurement of patient-reported outcomes (PRO) such as HRQOL, evaluation of prognostic indicators and identification of problems can occur in order to compare therapies and allocate resources.

\section{Acknowledgments}

This study was partially funded by grants from the Children's Medical Center Foundation and National Institutes of Health (U54 HL70588).

The authors wish to thank June Marshall, MSN, RN and Dolores Isham-Colvard, Ph.D., RN for their thoughtful review and comments and the children and families who participated in this study. We also appreciate the assistance of Sandra Richardson in providing information from the Center's Sickle Cell Database regarding potential study participants.

\section{References}

American Academy of Pediatrics, Section on Hematology/Oncology, Committee on Genetics. Health supervision for children with sickle cell disease. Pediatrics. 2002; 109:526-535. [PubMed: 11875155]

Ballas, SK.; Barton, FB.; Waclawiw, MA.; Swerdlow, P.; Eckman, JR.; Pegelow, CH., et al. Hydroxyurea and sickle cell anemia: Effect on quality of life. Health and Quality of Life Outcomes. [Retrieved February 8, 2008]. August2006 from http://hqlo.com/content/4/1/59

Brouwer CNM, Maille AR, Rovers MM, Veenhoven RH, Grobbee DE, Sanders EAM, Schilder AGM. Effect of pneumococcal vaccine on quality of life of children with recurrent otitis media: A randomized, control trial. Pediatrics. 2005; 115:273-279. [PubMed: 15687432]

Ferrans CE. Quality of life: Making sense of a multidimensional concept. Nurse Investigator. 1995; 2:9.

Fuggle P, Shand PAX, Gill SC, Davies S,C. Pain, quality of life, and coping in sickle cell disease. Archives of Diseases of Childhood. 1996; 75:199-203.

Gold JI, Yetwin AK, Mahrer NE, Carson MC, Griffin AT, Palmer SN, et al. Pediatric chronic pain and health-related quality of life. Journal of Pediatric Nursing. 2009; 24:141-150. [PubMed: 19268235]

Hankins J, Hinds P, Day S, Carroll Y, Chin-Shang L, Garvie P, et al. Therapy preference and decisionmaking among patients with severe sickle cell anemia and their families. Pediatric Cancer and Blood. 2007; 48:705-710. 
Human Genome Project. Genetic disease profile: Sickle cell anemia. [Retrieved November 18, 2009]. 2005 genomics.energy.orgfrom http://www.ornl.gov/sci/techresources/Human_Genome/poster/chromosomes/sca.shtml

Lee GM, Gortmaker SL, McIntosh K, Hughes MD, Oleske JM. Quality of life for children and adolescents: Impact of HIV infection and antiviral treatment. Pediatrics. 2006; 117:273-283. [PubMed: 16452344]

McClish DK, Penberthy LT, Bovbjerg VE, Roberts JD, Aisiku IP, Levenson JL, Roseff SD, Smith WR. Health related quality of life in sickle cell patients: The PiSCES project. Health and Quality of Life Outcomes. 2005; 50:1-7.

Okpala I, Thomas V, Westerdale N, Jegede T, Raj K, Daley S, et al. The comprehensive care of sickle cell disease. European Journal of Haematology. 2002; 68:152-162.

Palermo TM, Schwartz L, Drotar D, McGowan K. Parental report of health-related quality of life in children with sickle cell disease. Journal of Behavioral Medicine. 2002; 25:269-283. [PubMed: 12055777]

Panepinto JA. Health-related quality of life in sickle cell disease. Pediatric Cancer and Blood. 2008; 51:5-9.

Panepinto JA, O'Maher KM, DeBaun MR, Loberiza FR, Scott JP. Health-related quality of life in children with sickle cell disease and parent perception. British Journal of Haematology. 2005; 130:437-444. [PubMed: 16042695]

Panepinto JA, O’Maher KM, DeBaun MR, Rennie KM, Scott JP. Validity of the Child Health Questionnaire for use in children with sickle cell disease. Journal of Pediatric Hematology and Oncology. 2004; 26:574-578.

Panepinto JA, Pajewski NM, Foerster LM, Sabnis S, Hoffman RG. Impact of family income and sickle cell disease on health-related quality of life of children. Quality of Life Research. 2008; 18:5-13. [PubMed: 18989755]

Ramsey LT, Woods KF, Callahan LA, Mensay GA, Barbeau P, Gutin B. Quality of life improvements for patients with sickle cell disease. American Journal of Hematology. 2001; 66:155-156. [PubMed: 11421301]

Serjeant GR. The clinical features of sickle cell disease. Baillieres Clinical Hematology. 1993; 6:93115.

Shankar S, Robison L, Jenney MEM, Todd HR, Wu E, Feusner J, Friedman D, Kane RL, Bhatia S. Health-related quality of life in young survivors of childhood cancer using the MinneapolisManchester Quality of Life-Youth Form. Pediatrics. 2005; 115:435-442. [PubMed: 15687453]

Speechley KN, Barrera M, Shaw AK, Morrison HI, Maunsel E. Health-related quality of life among children and adolescent survivors of childhood cancer. Journal of Clinical Oncology. 2006; 24:2536-2543. [PubMed: 16735706]

Stengenga KA, Ward-Smith P, Hinds PS, Routhieaux JA, Woods GM. Quality of life among children with sickle cell disease receiving chronic transfusions. Journal of Pediatric Oncology Nursing. 2004; 21:207-213. [PubMed: 15490865]

Strickland OL, Jackson G, Gilead M, McGuire DB, Quarles S. Use of focus groups for pain and quality of life assessment in adults with sickle cell disease. Journal of the National Black Nurses Association. 2001; 12:36-43. [PubMed: 11902019]

Swallen KC, Reither EN, Haas SA, Meier AM. Overweight, obesity, and health-related quality of life among adolescents: The National Longitudinal Study of Adolescent Health. Pediatrics. 2005; 115:340-347. [PubMed: 15687442]

Testa MA, Simonson DC. Assessment of quality of life outcomes. Current Concept. 1996; 334:835840.

Thomas VJ, Taylor LM. The psychological experience of people with sickle cell disease and its impact on quality of life: Qualitative findings of a focus group. British Journal of Health Psychology. 2002; 7:345-363. [PubMed: 12614505]

Varni JW, Burwinkle TM, Seid M. The PedsQL 4.0 as a school population health measure: Feasibility, reliability, and validity. Quality of Life Research. 2006; 15:203-215. [PubMed: 16468077] 
Varni JW, Burwinkle TM, Seid M, Skarr D. The PedsQL TM 4.0 as a pediatric population health measure: Feasibility, reliability, and validity. Ambulatory Pediatrics. 2003; 3:329-341. [PubMed: 14616041]

Varni JW, Seid M, Knight TS, Uzark K, Szer IS. The PedsQL ${ }^{\text {TM }}$ 4.0 Generic Core Scales: Sensitivity, responsiveness, and impact on clinical decision-making. Journal of Behavioral Medicine. 2002; 25:175-193. [PubMed: 11977437]

Varni JW, Seid M, Kurtin PS. The PedsQL TM 4.0: Reliability and validity of the Pediatric Quality of Life Inventory ${ }^{\mathrm{TM}}$ Version 4.0 Generic Core Scales in healthy and patient populations. Medical Care. 2001; 39:800-812. [PubMed: 11468499]

Wethers D. Sickle cell disease in children: Part II. Diagnosis and treatment of major complications and recent advances in treatment. American Family Physician. 2000; 62:1309-1314. [PubMed: 11011859]

Williams J, Wake M, Hesketh K, Maher E, Waters E. Health-related quality of life of overweight and obese children. Journal of the American Medical Association. 2005; 293:70-76. [PubMed: 15632338]

World Health Organization. Preamble to the Constitution of the World Health Organization as adopted by the International Health Conference; New York. 19-22 June, 1946; signed on 22 July 1946 by the representatives of 61 States (Official Records of the World Health) 


\section{Table I}

Demographic \& Medical History Characteristics*

\begin{tabular}{|c|c|c|}
\hline Demographics & $\mathbf{n}$ & $\operatorname{Mean}(S D)$ \\
\hline Child's Age (yrs) & 124 & $13.0(3.3)$ \\
\hline \multirow[t]{2}{*}{ Grade in School } & 124 & 7.1(3.2) \\
\hline & $n$ & Percent \\
\hline \multicolumn{3}{|l|}{ Child's Gender } \\
\hline Female & 60 & $48.4 \%$ \\
\hline Male & 64 & $51.6 \%$ \\
\hline \multicolumn{3}{|l|}{ Respondent's Relation } \\
\hline Mother & 97 & $78.2 \%$ \\
\hline Father & 15 & $12.1 \%$ \\
\hline Grandmother & 5 & $4.0 \%$ \\
\hline Guardian & 7 & $5.7 \%$ \\
\hline \multicolumn{3}{|l|}{ Mother's Education } \\
\hline Grade $9-12$ & 24 & $19.8 \%$ \\
\hline High School Graduate & 36 & $29.8 \%$ \\
\hline Some College & 45 & $37.2 \%$ \\
\hline College Graduate & 10 & $8.3 \%$ \\
\hline Graduate education & 6 & $4.9 \%$ \\
\hline \multicolumn{3}{|l|}{ Father's Education } \\
\hline$<6^{\text {th }}$ Grade & 4 & $4.5 \%$ \\
\hline Grade 7 - 9 & 1 & $1.1 \%$ \\
\hline Grade $9-12$ & 19 & $21.3 \%$ \\
\hline High School Graduate & 31 & $34.8 \%$ \\
\hline Some College & 18 & $20.2 \%$ \\
\hline College Graduate & 12 & $13.5 \%$ \\
\hline Graduate education & 4 & $4.5 \%$ \\
\hline Days of School Missed & 98 & $3.6(5.4)$ \\
\hline Days Too Ill to Play & 117 & $3.2(4.4)$ \\
\hline Days of Care Needed & 113 & $3.4(5.6)$ \\
\hline \multirow[t]{2}{*}{ Days of Work Missed } & 103 & $2.4(2.6)$ \\
\hline & $n$ & Percent \\
\hline \multicolumn{3}{|l|}{ Diagnosis } \\
\hline SS & 118 & $95.2 \%$ \\
\hline$S \beta^{0}$ thal & 6 & $4.8 \%$ \\
\hline \multicolumn{3}{|c|}{ Hospitalization Past 12 months } \\
\hline Yes & 62 & $50.0 \%$ \\
\hline No & 52 & $50.0 \%$ \\
\hline
\end{tabular}

ER Visit in Past 12 months

$\begin{array}{lll}\text { Yes } & 91 & 74.0 \% \\ \text { No } & 32 & 26.0 \%\end{array}$




\begin{tabular}{lcr}
\hline Demographics & n & Mean (SD) \\
\hline $\begin{array}{l}\text { Child's Health Interferes with Respondent's Daily Routine } \\
\text { at Work }\end{array}$ & 36 & $39.1 \%$ \\
Never & 14 & $15.2 \%$ \\
Almost Never & 24 & $26.1 \%$ \\
$\quad$ Sometimes & 13 & $14.1 \%$ \\
Often & 5 & $5.4 \%$ \\
Almost Always & & \\
Child's Health Interferes with Respondent's Ability to \\
Concentrate \\
$\quad$ Never & 33 & $35.5 \%$ \\
Almost Never & 13 & $14.0 \%$ \\
Sometimes & 22 & $23.7 \%$ \\
Often & 19 & $20.4 \%$ \\
Almost Always & 6 & $6.5 \%$ \\
* &
\end{tabular}




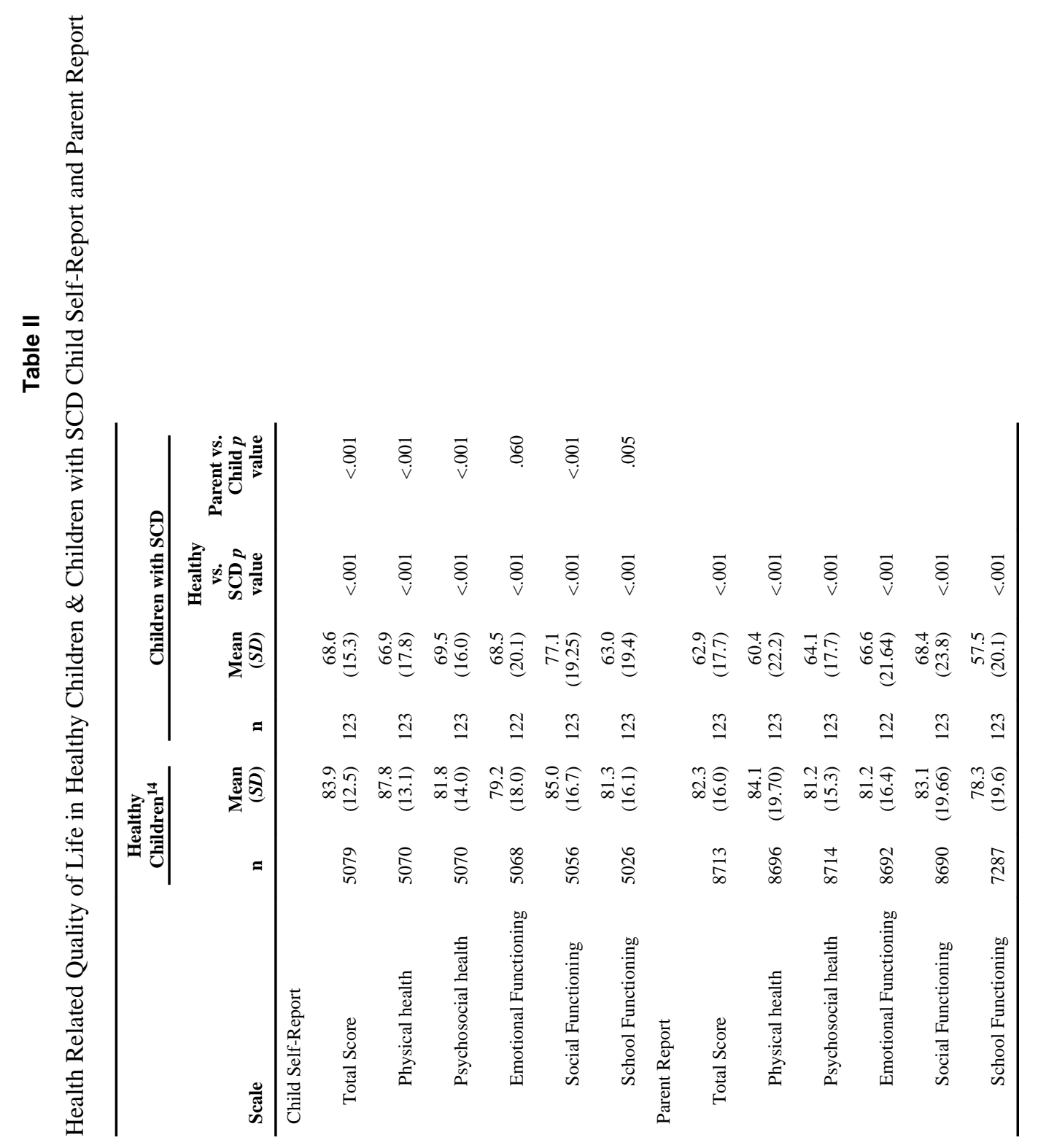


ชิ

定

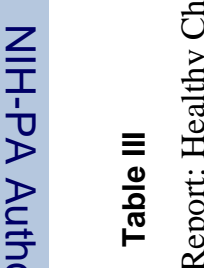

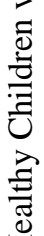

\begin{tabular}{|c|c|c|c|c|c|c|c|c|c|c|c|c|c|c|c|}
\hline \multirow{3}{*}{ 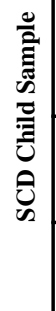 } & 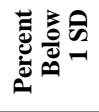 & & $\stackrel{8}{m}$ & ळ̊ํํ & ळे & ఏి & $\stackrel{\circ}{\stackrel{\infty}{\sim}}$ & 各 & & $\frac{5}{6}$ & 응 & $\stackrel{\circ}{\circ}$ & 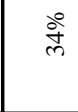 & $\dot{b}^{\circ}$ & $\stackrel{\circ}{\circ}$ \\
\hline & $\mathrm{z}$ z & & 8 & $\stackrel{\infty}{\sim}$ & $\stackrel{\infty}{+}$ & i & dे & $\infty$ & & $\stackrel{n}{\sim}$ & $\infty$ & 8 & F & in & $\ddot{\infty}$ \\
\hline & 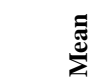 & & $\begin{array}{l}0 \\
\dot{0} \\
\dot{0}\end{array}$ & 官 & : & $\begin{array}{l}n \\
\infty \\
\infty\end{array}$ & $\vec{E}$ & ㅇ. & & فे & t. & ت্t & : & $\stackrel{+}{\infty}$ & in \\
\hline & & & & & & & & & & & & & & & \\
\hline \multirow{4}{*}{ 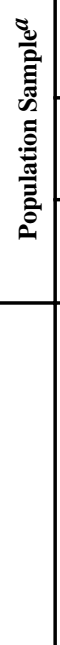 } & कि & & ä & 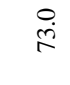 & : & in & ن. & 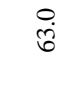 & & $\begin{array}{l}\ddot{8} \\
\ddot{B}\end{array}$ & జु. & $\underset{f}{+}$ & ڤ్రి & $\overline{\mathrm{j}}$ & $\begin{array}{l}\text { 足 } \\
\stackrel{\leftrightarrow}{n}\end{array}$ \\
\hline & हृ & & 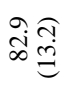 & 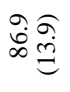 & 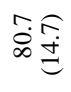 & 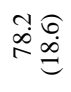 & 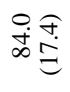 & $2 \hat{\sigma} \hat{\theta}$ & & 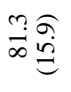 & $\begin{array}{l}m \\
\infty \\
\infty\end{array}$ & 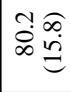 & 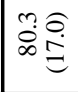 & 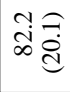 & 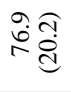 \\
\hline & $=$ & & 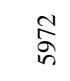 & ڤั & कू & क्षे & 京 & $\begin{array}{l}\infty \\
\text { ڤ్ } \\
\text { in }\end{array}$ & & $\stackrel{8}{\circ}$ & 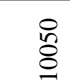 & $\overrightarrow{\mathrm{s}}$ & 志 & $\begin{array}{l}0 \\
\stackrel{0}{0}\end{array}$ & 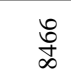 \\
\hline & $\begin{array}{l}\stackrel{0}{\tilde{J}} \\
\text { nू }\end{array}$ & 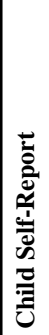 & 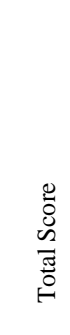 & 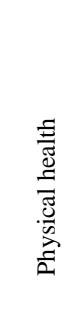 & 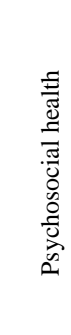 & 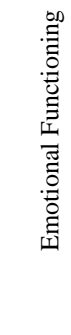 & 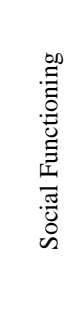 & 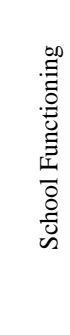 & 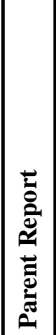 & 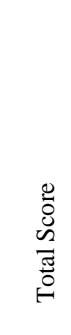 & 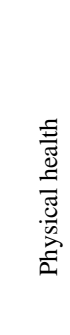 & 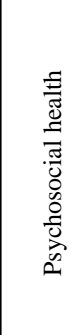 & 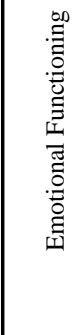 & 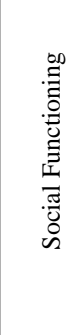 & 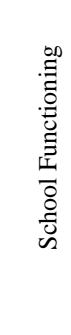 \\
\hline
\end{tabular}

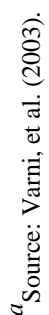

J Pediatr Health Care. Author manuscript; available in PMC 2012 July 1. 